\title{
The Impact of Austerity on Policy Capacity in Local Government
}

\author{
Peter Eckersley ${ }^{1}$ \\ Paul Tobin ${ }^{2}$ \\ ${ }^{1}$ Nottingham Trent University \\ ${ }^{2}$ University of Manchester
}

\begin{abstract}
:
Scholars have found it difficult to identify the impact of austerity on policy outputs. This difficulty may have arisen because studies focus on the content of national and EU legislation, or budgetary responses to fiscal constraint, rather than taking a holistic view of 'policy'. Drawing on fieldwork in two English cities, we show how 'dismantling by arena shifting' - exemplified by reductions in 'back-office' environmental policy capacity at the subnational level - can provide a more nuanced understanding of national-local interaction and policy change. We propose that such approaches may be common, because they allow policymakers to protect electorally popular 'front-line' services and more visible aspects of public goods provision, thereby avoiding blame for potentially unpopular decisions.

However, dismantling by arena-shifting may have significant impacts over the medium-term, because reductions in 'back-office' functions may make it more difficult for subnational actors to develop, implement and enforce effective policy in future.
\end{abstract}

\section{Key words:}


Austerity; policy capacity; policy dismantling; national government; local government; environmental policy; service provision

\section{Word count:}

6149 (excluding references, charts and tables)

\section{Introduction}

The election of the UK's Conservative-Liberal Democrat coalition government in 2010 resulted in a period of ongoing austerity in the country, promulgated by the national government and with attendant cuts to local administrations (Lowndes and Gardner 2016). Such tight fiscal policies in the UK and elsewhere, along with rhetoric around the need to 'cut red tape', have triggered something of a revival of studies into policy 'dismantling' (Bauer et al, 2012; Schaffrin et al, 2015; Davidescu et al, 2018; Burns et al, 2019a; Pollex and Lenschow, 2019), as scholars have tried to identify whether and how governments are involved in the "cutting, diminution or removal of existing policy" (Jordan et al, 2013, 795). These studies have focused largely on attempts to remove regulatory constraints on businesses, but they have found only limited evidence of the European Union (EU) and national governments having weakened regulations, despite politicians arguing in favour of removing such 'burdens' in order to try and stimulate private sector-led growth (Gravey and Jordan, 2016; Steinebach and Knill, 2017).

Additionally, a different group of scholars have focused upon the ways governments have introduced organisational restructures, rescaling, service reductions and other approaches to try and cope with fewer resources (Schmidt et al, 2017; Lampropoulou, 2018). Many of these 
studies have examined the local level in particular, where the impact of austerity cuts has been felt most keenly in several countries (Lowndes and McCaughie, 2013; Cepiku et al, 2016; Davies and Blanco, 2017; Chorianopolous and Tselepi, 2019; Pill and Guarneros-Meza, 2018). However, the studies either tend to focus on 'cutback management' and the budgetary challenges of dealing with austerity (Di Mascio and Natalini, 2015; Sørensen et al, 2017; Ferry et al, 2017; Steccolini et al, 2017), or on the social costs of reducing the scope of public provision (Hastings et al, 2015; Morris, 2016; Webb and Bywaters, 2018). Few studies have examined how policy may have changed as a result of these initiatives - if we understand policy to be 'the sum total of government action, from signals of intent to the final outcomes' (Cairney, 2016, 2, our emphasis). As numerous scholars have pointed out, focusing solely on the content of 'high-level' legislation cannot reveal a full picture of how and why policy might be changing 'lower down' the chain (Cairney, 2016; Sausman et al, 2016; Bondarouk and Mastenbroek, 2018; Lenschow and Pollex 2019). Similarly, we need to work back 'up' from service reductions and cutback management approaches to track how these changes may be affecting overall policies. For example, there is a possibility that legislative and regulatory requirements may remain unaltered, but a lack of resources to implement and enforce them could mean that some policies become eviscerated 'zombies' - either by design or default (Bob, 2012).

As such, how can we bring dismantling and cutback management perspectives together to create a more complete account of how policy may be changing? Bauer and Knill's comprehensive conceptualisation of policy dismantling provides useful signposting here, particularly when they note that dismantling 'can be achieved by manipulating the capacities to implement and supervise' core elements of policy (Bauer and Knill, 2012, 6). This conceptualisation suggests that restricting policy capacity - by reducing the resources (such as staff, money, or information) upon which the state can draw to make intelligent, informed choices about different strategic alternatives (Howlett and Lindquist, 2004) - might represent 
a route through which policymakers seek to dismantle existing levels of provision. Since this strategy is likely to be more discreet than high-profile cuts to welfare, for example, it has echoes of Bauer and Knill's (2012) concept of dismantling by arena shifting - defined as dismantling that is pursued deliberately by policymakers, and is not highly visible, because it involves transferring responsibilities away from high-profile departments and agencies.

In the same way, we might expect functions such as policy development, implementation, monitoring, enforcement and evaluation to be the target of dismantling strategies, because they are often conducted at arms-length from both central government and 'front-line' service delivery. Focusing cuts in these areas may enable policymakers to depoliticise and avoid the blame for unpopular decisions, whilst taking credit for any reductions in public spending (and, by extension, taxation), and citizens might be less likely to notice any adverse impact on public goods provision (Hastings et al, 2013; Fitzgerald and Lupton, 2015) - at least initially. Yet, despite recognition that the level of government capacity influences policymaking (Matthews, 2012; Lodge and Wegrich, 2015; Kim and Yoon, 2018; Eckersley, 2018), studies do not make explicit links between the possible weakening of these functions and the concept of policy dismantling. We bridge these existing research literatures to establish our theoretical approach, which provides a more nuanced understanding of national-local interaction and policy change, and helps to demonstrate empirical manifestations of policy dismantling.

We begin by reviewing the literature on policy dismantling, cutback management, and policy capacity, and show how a combination of these approaches may help to paint a more complete picture of how policies change. Following the methods section, we apply our theoretical approach to environmental policy within English local government to explore the weakening of policy capacity within this sector since 2010. Crucially, we argue that scholars might have found policy dismantling elusive in previous empirical studies for two reasons. First, studies 
may have been looking in the wrong place, because most research into policy dismantling examines the EU and national governments. Second, scholars may also have been trying to find the wrong 'type' of dismantling, because previous research has focused overwhelmingly on regulatory standards and welfare payments, rather than the capacities required to inform and develop policy initiatives that respond to new and emerging challenges. The ensuing discussion highlights how our approach can provide a more holistic understanding of policy change.

\section{Theoretical approach}

\section{$\underline{\text { Policy dismantling }}$}

Studies of 'policy dismantling' began to gain traction after Pierson's (1994) seminal analysis of welfare retrenchment in the UK and US, which highlighted the difficulties associated with reducing public provision. Subsequent research found that although it may be relatively straightforward for politicians to announce budgetary reductions (particularly if they are accompanied by tax cuts), it is often less easy to dismantle existing levels of provision once client groups and voters become aware of how they might be affected (Jordan et al, 2012).

The term 'dismantling' is wider in scope than 'cutbacks', or 'retrenchment', which are hallmarks of research into welfare policy: 'dismantling' encompasses regulatory weakening alongside spending reductions, to reflect the various strategies governments might adopt in the face of opposition to retrenchment (Bauer et al, 2012). Notably, however, scholars have found it difficult to identify substantial dismantling of either (re)distributive policies or regulations. This struggle may exist because policymakers are reluctant to reduce the level of public welfare provision or the stringency of regulations in highly visible ways - what Bauer et al (2012) call active dismantling - because they suspect that such actions may be electorally unpopular. Nonetheless, politicians have expressed a desire to reduce public spending or 'red tape', particularly since the 2007/2008 Global Financial Crisis (Pimlott and Giles, 2010). 
Bauer et al (2012) identify four ideal types of dismantling, differentiated by whether the dismantling involves an active decision or not, and is highly visible or not (see Table 1). In addition to active dismantling, we are interested in the other strategy that involves a deliberate dismantling decision, dismantling by arena shifting. Unlike active dismantling, dismantling by arena shifting is not highly visible, and involves policymakers shifting responsibility for certain functions to another institution (such as a different level of government or external agency). Dismantling by arena shifting could be a common strategy, because it allows politicians to avoid some of the blame for potentially unpopular decisions (Bauer and Knill, 2012). Yet, to date, this type of dismantling has received limited empirical research, especially regarding the manifestations through which it is achieved.

\begin{tabular}{|l|l|l|}
\hline & High visibility & Low visibility \\
\hline Deliberate dismantling & Active dismantling & Dismantling by arena shifting \\
\hline No dismantling decision & Dismantling by symbolic action & Dismantling by default \\
\hline
\end{tabular}

Table 1: The four ideal types of policy dismantling developed by Bauer and Knill (2012).

We may lack empirical evidence of dismantling by arena shifting because - by definition - it requires scholars to look beyond high-level policies or items of legislation agreed by elite actors, and instead examine how decisions are interpreted, implemented and enforced 'on the ground'. Most of the dismantling literature focuses on specific instruments where a clear legal baseline exists against which to monitor any change, such as EU regulations (Gravey and Jordan, 2016; Steinebach and Knill, 2016), or the level of welfare payments (Green-Pedersen et al, 2012; Bianculli et al, 2012). This attention is not especially surprising, as any changes to these instruments are straightforward to recognise, and the small number of intervening 
variables facilitates the identification of causal links. However, focusing on supranational and national policymaking risks neglecting factors and actors that shape how policies are put into effect, and therefore is unlikely to reflect completely whether and how they may change.

\section{Cutback management}

There is an established literature on how policymakers engage in 'blame avoidance' strategies when they suspect that policies may be unpopular (Hood, 2010; Howlett, 2014). Surprisingly, however, scholars have rarely applied the dismantling concept to subnational bodies. As research into austerity and depoliticisation has identified, by cutting funding for subnational actors, high-level policymakers can claim the credit for reducing overall public expenditure, whilst insulating themselves from any political fallout (Standring 2018). Yet, despite the fact that subnational or agency bodies could represent fertile terrain for examining dismantling, most research into their responses to austerity have built on the 'cutback management' literature (Levine, 1978; Dunsire et al, 1989) by focusing on budgetary or organisational strategies that individual organisations have adopted to cope with fewer resources (Lowndes and McCaughie, 2013; Hastings et al, 2015; Cepiku et al, 2016; Kuhlmann and Bouckaert, 2016; Steccolini et al, 2017).

This literature tends to focus on bureaucracies rather than political decision-making and often stresses the distinction between 'front-line' service delivery and 'back office' administrative functions. Earlier studies suggested that senior decision-makers do not necessarily slim down 'back-office' functions in response to revenue pressures (Freeman and Hannan 1975; McKinley 1987; Meier and O’Toole 2009), but we would not necessarily expect the findings of such studies to be repeated in our research, for several reasons. First, we examined large urban authorities, and Boyne and Meier (2013) found that only small organisations respond to external shocks by expanding the bureaucracy. Second, we sought to determine how funding 
cuts might affect proactive policymaking and attempts to respond to new environmental policy problems as they emerge, whereas these studies stress a defensive and reactive urgency on behalf of managers to protect 'core performance' in the face of fiscal constraints (Meier and O'Toole 2009, 497). Third, the political context within which our local authorities were operating encouraged them to cut administrative budgets rather than reduce the number of highly-visible street-level bureaucrats (Gershon, 2004; Elston and Dixon, 2019). Indeed, Hastings et al (2013) and the National Audit Office (2018a) found that UK local authorities adopted this strategy in response to austerity. Fourth, and in line with the theoretical argument that politicians prefer low-visibility approaches for dismantling, the political costs of scaling back policymaking functions are likely to be lower than those associated with cutting frontline workers who make a more visible contribution to the public.

Because studies in this field tend to focus on bureaucracy, they often neglect the relationship between changes in the resourcing of front-line services or back office functions and policymaking. Where studies do make this link, they employ the language of 'retrenchment', 'rationing' or 'cutbacks' (Kim and Warner, 2016), reflecting their overwhelming focus on (re)distributive policies, such as welfare (Fitzgerald and Lupton, 2015), or children's services (Webb and Bywaters, 2018). Some scholars have examined local environmental goods (such as air quality, parks, recreation, street cleansing or planning regulation), but they predominantly come from a social justice perspective rather than adopting a dismantling lens (Hastings, 2009; Bramley et al, 2012; Davoudi and Bell, 2016). Yet, we would argue that local environmental services are particularly vulnerable to dismantling pressures. This vulnerability results from policymakers at the 'top' relying on various different organisations at the 'bottom' to implement environmental objectives (Wurzel et al, 2013) - but if subnational bodies are experiencing fiscal constraints they may no longer allocate sufficient resources to the environment. Furthermore, municipalities in many countries are not mandated to provide a 
certain level of environmental protection (Goldsmith and Page, 2010). Plus, the beneficiaries of environmental policy dismantling tend to be limited to a few powerful actors (such as, at the local level, heavy industry, building companies, and developers), whereas the costs are often distributed across the community. This differentiation makes it more difficult to mobilise effective opposition towards any potential weakening of existing provision (Jordan et al, 2012), which Pierson (1994) argued increases the chances of dismantling.

Overall, therefore, it is possible that environmental policy has weakened due to public spending cuts, but it may have occurred out of sight of those who are responsible for imposing resource constraints at the subnational level - and also of scholars who have tried to find evidence of dismantling. As the next section shows, this weakening could have a subtle but profound impact on policy delivery, because it may reduce the state's capacity to develop, implement and evaluate policy effectively.

\section{Policy capacity}

The concept of 'policy capacity' is highly contested, partly due to the difficulties associated with its conceptualisation and measurement (Bali and Ramesh, 2018). Nevertheless, there is general agreement that it refers to the state's ability to direct resources, and make intelligent, informed choices about different policy and strategic alternatives (Howlett and Lindquist, 2004; Painter and Pierre, 2005; Peters, 2015; O’Toole and Meier, 2010). Although 'it is a cliché to argue having adequate policy capacity is a necessary pre-condition for policy success' (Wu et al, 2015, 165-66), we can surmise that funding reductions for subnational bodies may affect their ability to make informed decisions and implement policy. Furthermore, actors with reduced capacity may decide to pursue less ambitious initiatives, in the knowledge that they would struggle to achieve loftier objectives. 
In operationalising policy capacity, Painter and Pierre (2005) identified 'intelligent choice' as a core indicator. Building on Weaver and Rockman (1993), they highlight expert staff, financial resources and organisational continuity as building blocks that help public bodies make intelligent policy choices. A related concept here is the analytical capacity of the public body, namely its ability to generate knowledge from policy-relevant information and use it to inform decision-making (Parrado, 2014). Fundamentally, therefore, where public bodies possess resources such as money, staff, relevant information and connections, they tend to be better placed to develop effective policies for achieving their objectives.

The policy capacity literature has focused on conceptualising the factors that contribute towards its development (Parsons, 2004), and on how public bodies can build capacity to increase their chances of achieving policy objectives in the age of globalisation (Jayasuriya, 2004). Empirical studies in the developed world also draw overwhelmingly on national government examples, particularly Canada and Australia (Howlett, 2009; Gleeson et al, 2011; Newman et al, 2017). In other words, we know little about how and why policy capacities may be weakening, particularly in Europe or at the subnational level. This lack of research is surprising: many European governments have cut funding for subnational bodies since 2010, and - as discussed above - we might expect policymakers at this level to implement budgetary cuts to 'back-office' functions (such as policy analysis, development and evaluation) rather than front-line public services. Therefore, weakening policy capacity at the subnational level could be a more common dismantling strategy than diluting high-level legislation, cutting central government budgets, or reducing the scope of front-line services. Indeed, weakening policy capacity may offer a theoretical bridge between legislative dismantling and operational 'cutback management', helping us to formulate a more holistic understanding of policy change.

\section{Methods}


We chose the UK as our case for several reasons. First, unlike Eurozone members such as Greece, Ireland and Portugal that implemented austerity measures as a condition of receiving financial bail-outs, the UK has pursued an austerity agenda of its own volition since 2010 . Thus, considering the absence of an external actor to blame for any negative impacts of spending cuts, the UK's national governments since 2010 may provide particularly good examples of 'low-visibility' policy capacity dismantling. Second, the UK possesses relatively weak subnational government (Goldsmith and Page, 2010), which could make it easier for national policymakers to devolve responsibility for potentially unpopular decisions. Third, central funding for English local authorities fell by 49\% between 2010 and 2018 (National Audit Office, 2018a), yet councils need to agree balanced revenue budgets every year, with limited flexibility to raise additional income (Ferry et al, 2017). These funding cuts have had an asymmetric impact across the country, largely because urban and northern authorities were more heavily dependent on central grants for their income (Gray and Barford, 2018). Therefore, northern English city councils may provide useful exploratory cases for understanding how environmental policy capacity is reduced in response to nationally-determined spending cuts.

We were keen to examine whether and how dismantling might be occurring, and to use our empirical findings to help build theory on policy capacity and dismantling, rather than test hypotheses drawn from existing perspectives. We therefore consulted relevant government legislation, audit and media reports and the grey literature on the impact of austerity on local public services, both to identify potential case study councils and to support our subsequent analysis of any change in their environmental policy approach. Thus, we examined two cities in northern England that experienced severe funding cuts between 2010 and 2018 (see Table 2). We chose two similar cities in order to reduce the risk that our findings related to just one case. Both cities were: heavily affected by funding cuts; controlled locally by the Labour Party 
(whereas the Conservatives dominated the national level during this period); and part of larger metropolitan areas.

During 2017-2018, we negotiated access to key practitioners in both cities and conducted indepth interviews of up to ninety minutes in length with a total of eleven senior officers and elected councillors. Although eleven interviewees might appear a small sample, we spoke to those working at the heart of this process, and their responses enabled us to generate detailed, illuminating pictures of how each city was changing its approach to environmental protection. The interviewees had responsibilities for planning, building control, parks and open spaces, waste management, economic development, climate change and trading standards. We selected our initial interviewees by examining council websites, before adopting a snowball approach to identify subsequent individuals. Mostly, we spoke to people with similar responsibilities in each council, but this was not always possible due to differing departmental structures. Our aim was to examine whether and how the councils might be dismantling environmental policy capacity, rather than compare the two cities specifically, and so interviewees' differing roles was not a major concern.

Reflecting the exploratory nature of our study, we encouraged our interviewees to identify their own examples of possible changes to service delivery since central government funding cuts began under the Conservative-Liberal Democrat coalition in 2010. We then coded the interview transcripts according to the policy area under discussion and the form of policy dismantling identified by the interviewee, before merging these coded concepts as part of our analysis. Our analysis revealed a common thread of internal resource constraints and a greater reliance on other actors for information, expertise and funding. We therefore conducted another coding exercise through which transcripts were categorised according to the type of resources that 
interviewees identified as important. We drew on both coding exercises when developing this article.

To corroborate these findings, we cross-referenced interviewees' responses with council and regional-level policy and meeting documents, as well as local media sources. We also consulted official statistics on council funding and expenditure published by the Ministry of Housing, Communities and Local Government, which underpin the National Audit Office's (2018b) online data visualisation tool for examining trends in council revenues and expenditure since 2010. Given the sensitive nature of the discussions, the names of the cities have been made anonymous. As such, we refer to them as Council A and Council B and have not referenced publicly-available sources that could help to identify them.

\section{Research findings}

Table 2 shows the scale of the funding cuts experienced by English local government between 2010 and 2018. Although funding for both of our councils was cut by around the national average of $49 \%$, they were less able to raise additional income than many other authorities, because a large share of domestic properties fell into lower bands for Council Tax; therefore, their 'revenue spending power' fell by a disproportionate amount. As Table 2 illustrates, Council A cut budgets for both environmental and regulatory services, and for planning and development, by much more than the English average; Council B reduced environmental and regulatory spending by significantly less.

In response to austerity measures, our fieldwork revealed examples of active policy dismantling, which highlighted how the councils felt that they had no option but to introduce highly visible and potentially unpopular policies that weakened public provision. For instance, one authority reduced the frequency of grass-cutting and litter picking (Interviewee, Council 
A), and also reduced significantly the number of flower planters around the city. These decisions hold biodiversity implications, which in turn may have a significant impact on the wider ecosystem:

Effectively there's zero grounds maintenance budget. You'll notice the beautification bedding planting has gone... We don't have money to send bowsers round in the summer, watering plants (Interviewee, Council A).

\begin{tabular}{|l|l|l|l|l|}
\hline & $\begin{array}{l}\text { \% change in } \\
\text { central } \\
\text { government } \\
\text { funding }\end{array}$ & $\begin{array}{l}\text { \% change in } \\
\text { 'revenue } \\
\text { spending power' }\end{array}$ & $\begin{array}{l}\text { \% change in } \\
\text { environmental and } \\
\text { regulatory services } \\
\text { budgets }\end{array}$ & $\begin{array}{l}\text { \% change in } \\
\text { planning and } \\
\text { development } \\
\text { budgets }\end{array}$ \\
\hline England & -49.1 & -28.5 & -16.9 & -52.8 \\
\hline Council A & -50 & -35 & -40 & -65 \\
\hline Council B & -50 & -40 & -5 & -50 \\
\hline
\end{tabular}

Table 2: Real-terms funding and spending reductions in the two councils, 2010/11-2017/18. All data from National Audit Office (2018b). Figures for Council A and Council B are rounded to the nearest $5 \%$ to maintain confidentiality

Notably, however, we also found changes that were difficult to categorise as either 'dismantling' or 'expansion' of existing policy. For example, both authorities used to collect recyclable household waste every fortnight and residual waste (for landfill or incineration) on a weekly basis. After they no longer received central funding to support weekly residual waste collections, the councils decided explicitly to move from weekly to fortnightly collections, with one city subsequently reducing the size of its bins from 240 to 140 litres. Taking a policy dismantling perspective, such a change would represent a lower level of public provision, particularly because the decision to move to alternate weekly collections was primarily financial (Interviewee, Council A). Yet, our fieldwork found that this shift held environmental benefits, because it encouraged residents to recycle more: 
To help nudge people towards recycling [you can] reduce the capacity for mixed waste collection, and one way to do that is go to alternate weekly collection... It does help push recycling rates up (Interviewee, Council A).

When there were large bins that were collected more frequently, there was little incentive to recycle; the view being that if you create a smaller black bin, and empty it every couple of weeks, you create that incentive - which has been successful. In terms of recycling, the rate has definitely gone up since we've done that (Interviewee, Council B).

The issue of policy change resulting in both environmental 'benefits' and 'drawbacks', and thereby being difficult to categorize as either expansion or retrenchment, is not new to the dismantling literature (see for instance Knill et al, 2010). Nonetheless, this example highlights some of the limitations of the dismantling terminology in trying to explain policy change.

In addition, our fieldwork revealed less obvious ways in which environmental policy had weakened since 2010. The planning sector was one area in which legislation remained unaltered but policy had shifted. For example, one officer explained how a change in ministerial rhetoric around the purpose of planning and building regulations after 2010 meant that councils across England suddenly became reluctant to stipulate that new developments would need to generate a certain percentage of their energy through on-site renewables. This shift occurred without any change in legislation:

The powers that local planning authorities have on the 2008 Act still stand. But there is a wide, shared, perception within the development community and local planning authorities that those powers aren't there, that they have been swept away. And that is completely erroneous (interviewee, Council A).

This interviewee from Council A noted that many experienced planners had left the public sector in recent years, exacerbating this lack of understanding within local government about 
the UK's sustainable development framework. This exodus highlights how reduced capacity might result in weaker policy almost by accident (and out of sight of central policymakers), because it can make it more difficult for public officials to track and make sense of the legal context within which they operate.

Council A also introduced substantial cuts to the 'back-office' in trading standards: one interviewee explained how their team shrank from fourteen to just four people between 2005 and 2018. Importantly, these cuts in 'bureaucracy' mean that the council is more reliant on external actors for policy-relevant information. Therefore, instead of inspecting businesses proactively to identify potential regulatory breaches, trading standards officers responded to residents' enquiries and then targeted their activities accordingly. The council's change in approach meant it focused on investigating breaches about which residents were more likely to complain, such as health and safety concerns or the sale of alcohol and tobacco to minors. As a result, the council had fewer resources to enforce environmental legislation, including laws prohibiting the sale of incandescent lightbulbs or products containing microbeads (interviewee, Council A). This example highlights how resource constraints can lead to changes in the type of information available to decision-makers, which may distort their knowledge of any particular policy problem, ultimately leading to reduced policy capacity. Indeed, previous studies have shown how an increasing reliance on external sources of policy-relevant information can mean that activity is skewed geographically towards those areas of each city in which affluent and articulate residents predominantly live (see Hastings, 2009).

Relatedly, both councils were working much more closely with other local actors to develop and deliver policy objectives. Often, this cooperation was part of a conscious and explicit strategy to access the capacity that was lacking within the authorities (see Eckersley, 2018). For example, Council A was investigating the possibility of transferring responsibility for some 
of its parks to an external organisation, while Council B was relying increasingly on regional partners for expertise and information to help develop its climate change strategy. As our interviewees recognised, these initiatives resulted in both authorities relinquishing some control over policy development, implementation and intelligence-gathering. On this last point in particular, they acknowledged that this loss of control increased the number of 'unknown unknowns' and could mean that their councils neglect problems as they begin to emerge because they are simply unaware of their existence. Councils would also have less awareness of which policy instruments or initiatives might be best suited to address the issue in question:

The complexities of working out a solution, then trying to bring in the money to deliver it, is quite a lot of work...I think increasingly we don't have those skills in the council any more (Interviewee, Council B).

In an ideal world, if you want to plan an initiative you might want to do some benchmarking, some work on best case studies or examples prior to considering how a particular programme might work... That capacity has reduced, and what you end up doing is launching straight into programmes because you haven't had individual pieces of research that would have helped you (Interviewee, Council B).

As such, we found evidence of a chain reaction of policy weakening, whereby dismantling by arena shifting (originating from the national level) led to reduced subnational policy capacity, which in turn resulted in additional, 'accidental' dismantling. Indeed, we might expect this impact to be a logical consequence of lower levels of policy capacity, which reduces the ability of policymakers to predict the impact of their activities on the future level of public goods provision.

\section{Discussion}


Previous studies may have found policy dismantling elusive because they were looking in the wrong places, or trying to identify the wrong types of dismantling. As such, we analysed lowvisibility spending cuts as a form of national-local interaction, in the hope that this focus would reveal clearer examples of the "cutting, diminution or removal of existing policy" as defined by Jordan et al $(2013,795)$. We identified several cases of active dismantling: since 2010, our two cities have reduced the frequency of litter picking and the extent of street beautification, for instance. More importantly, we found a weakening of policy capacity: both councils now have far fewer resources to develop, implement, oversee, enforce and evaluate policy within their localities. This change means they have less knowledge about the extent and nature of environmental issues, and therefore less awareness of which policies and instruments might be able to address them effectively. Both councils were seeking to access extra resources from other local partners in order to increase their capacity. However, pursuing this approach involves relinquishing some control over intelligence-gathering and policymaking processes, and could mean that the authorities are less well-prepared to deal with emerging and future problems.

\section{$\underline{\text { Research challenges }}$}

Despite gathering these findings, we faced several methodological challenges that future studies into the dismantling of subnational policy capacity may also encounter, and which could mean that researchers will never be able to measure dismantling satisfactorily. First, the politically sensitive nature of the issue can make it difficult to find individuals who are willing to discuss the topic. For example, some of our interviewees were reluctant to draw attention to the fact that they no longer had the resources to implement or enforce legislation effectively and were conscious that this could put them in a difficult position with their superiors. Relatedly, assessing whether 'deliberate' yet low-visibility dismantling has been pursued at the 
national level would require those making cuts to admit that they sought to obscure the impacts of their actions from the electorate.

In addition, all of our interviewees stressed that any weakening of policy was not part of a deliberate strategy on their part, but rather a logical or even necessary outcome of fiscal constraint. Therefore, and consistent with our assumed rationale for why policymakers might adopt a strategy of dismantling by arena shifting, it is difficult to assign responsibility for specific policy changes to any particular individual: lines of accountability may be obscured by complex collaborative governance arrangements, the passage of time, or the removal of decision-makers from office. As a result, scholars may only be able to identify dismantling once resources have been cut, capacity has been restricted, and certain services have been prioritised. Thus, making causal links to fiscal policies associated with specific individuals several years earlier is likely to prove difficult.

In addition to its acknowledged limited focus on legislation, our study also highlighted some further shortcomings of the dismantling perspective, because concentrating on policy strengthening, stasis or weakening may be too simplistic (on policy stasis, see Burns et al, 2019b). As we found, although moving to fortnightly residual waste collections reduced the scope of governmental provision and only occurred after central government stopped providing ring-fenced grants for a weekly service, it helped both councils to increase recycling rates and therefore contributed towards achieving this environmental policy objective. This example raises a further issue: should we judge changes in policy according to their perceived objectives - and if the overriding priority is to reduce public expenditure, then would such a decision represent dismantling? Making an assessment of actor preferences is fraught with challenges: policymakers may seek to conceal why they took a particular decision for electoral reasons, and multiple factors often account for a change in policy. We did not seek to make any such 
judgements in our study, but these concerns nonetheless highlight some of the epistemological drawbacks associated with trying to identify and measure policy weakening or strengthening. Indeed, it may be more productive to talk about policy change rather than try to place such shifts into binary categories - even if doing so may reduce the potential utility of the dismantling perspective.

Finally, the specific case of environmental protection raises particular issues for the concept of dismantling. Scientists identify new environmental concerns over time, and therefore governments should propose new legislation and policy initiatives in response to these emerging problems (Weale, 1999). As a result, what may appear to be policy stasis may actually represent dismantling by default (the form of dismantling defined by Bauer et al (2012) as both low-visibility and without a preceding dismantling decision). Therefore, we can see how any weakening of the capacity to inform, develop, enforce and evaluate new environmental policy in response to societal and scientific developments could represent a specific - and potentially significant - way in which dismantling might occur.

\section{Contributions and future research}

We argue that the concepts of dismantling by arena shifting and policy capacity can help scholars to 'zoom out' and view a bigger landscape of how policy may be changing. If we work on the basis that higher-level policymakers are rational actors who fear dismantling will be electorally unpopular, we can see how they may be more likely to reduce funding to external organisations that are often characterised as wasteful and/or bureaucratic (such as local authorities) rather than introduce more visible initiatives that weaken existing levels of provision. As such, we might expect dismantling by arena shifting to be more common in countries where intergovernmental relations are highly asymmetric (such as England), and where subnational bodies are more reliant on the centre for resources. These subnational bodies 
may in turn try to maintain a public presence of 'street-level' service delivery to reduce the political fallout, and therefore cut spending in those 'back-office' areas that are less visible to citizens.

We would encourage further research to be conducted on the subnational level, across the UK and in other austerity-affected states, to build upon our theoretical contribution. Such studies could employ the concept of policy capacity as a bridge between 'cutback' strategies and the dismantling literature, to help examine how the service reductions that often result from fiscal constraint may relate to overall policies. Reducing the amount of resources that help to develop, implement and enforce policy will affect the provision of public goods, and therefore we argue that policy capacity can provide a useful lens for examining change. The impact of weakened policy capacity will probably be slower and less transparent than cuts to welfare benefits, a lowering of regulatory standards, or a reduction in front-line services, but it is still likely to be significant. We can apply the same principles to central government departments and agencies elsewhere, such as the US Environmental Protection Agency, which has experienced significant funding cuts during Donald Trump's presidency (Bomberg, 2017).

We would also welcome further research into whether this pattern may hold particularly acute implications regarding transboundary environmental issues such as climate change, or indeed to other policy sectors. In particular, if responsibility is passed to the local level without attendant increases in resources, priorities may shift towards local environmental challenges that are more easily comprehended and addressed in the short-term by local communities, rather than more complex or international problems (see Tobin, 2017, 42). Furthermore, transboundary challenges are often time-sensitive and irrevocable, suggesting that short periods of austerity could significantly impede the mitigation of long-term environmental issues. As such, we encourage further studies into the prioritisation of certain environmental 
challenges over others in a context of financial cutbacks and the attendant impacts on local policy capacity, alongside the effect of these changes on citizens' perceptions of the existing levels of environmental protection. Additionally, studies of cases where intergovernmental relations are less asymmetric, and characterised by partnership rather than hierarchy, could generate valuable comparative knowledge of how different multi-level systems shape policy processes across tiers of government. Finally, further analysis of how collaboration and partnerships are being used to mitigate the effects of cuts (see Pill and Guarneros-Meza 2018; Chorioanopolous and Tselepi 2019), would be a welcome addition the literature.

\section{Conclusions}

As we have argued, scholars may have hitherto been looking in the wrong places to try to find concrete examples of dismantling, perhaps explaining why they have found it so difficult to identify examples of the phenomenon. With this in mind, studies of policy dismantling should follow the lead of research into policymaking and seek to understand the actions of all relevant actors in the policy 'chain' or 'cycle' in order to arrive at a more rounded explanation of change (Cairney 2016). Such studies might also adopt similar theories to try and understand how and why policy may be changing. We suggest that our consolidated approach for identifying and analysing low-visibility dismantling - through examination of restrictions to policy capacity as a form of national-local interaction - could provide one way to support further research into this area, at a time in which multiple crises are afflicting policymaking arenas.

This work was supported by the Leverhulme Trust under Grant RPG-2014-183. The Authors declare that there is no conflict of interest. 
We would like to thank Charlotte Burns and the two anonymous reviewers for their helpful comments on previous drafts of this article.

\section{References}

Bauer, MW, Knill, C, 2012, Understanding policy dismantling: an analytical framework, in Bauer, MW, Jordan, A, Green-Pedersen, C, Héritier, A (eds), Dismantling Public Policy: Preferences, Strategies, and Effects, Oxford Scholarship online, doi: 10.1093/acprof:oso/9780199656646.003.0002

Bali, AS, Ramesh, M, 2018, Policy capacity: A design perspective, in Howlett M, Mukherjee I, (eds), Routledge Handbook of Policy Design, London: Routledge

Bauer, MW, Jordan, A, Green-Pedersen, C, Heritier, A, 2012, Dismantling public policy: preferences, strategies, and effects, in Bauer, MW, Jordan, A, Green-Pedersen, C, Héritier, A (eds), Dismantling Public Policy: Preferences, Strategies, and Effects, Oxford Scholarship online, doi: 10.1093/acprof:oso/9780199656646.003.0009

Bianculli, AC, Jenne, N, Jordana, J, 2012, From dismantling by default to arena shifting: child benefits policy in Spain, in Bauer, MW, Jordan, A, Green-Pedersen, C, Héritier, A (eds), Dismantling Public Policy: Preferences, Strategies, and Effects, Oxford Scholarship online, doi: 10.1093/acprof:oso/9780199656646.003.0005

Bob, C, 2012, The Global Right Wing and the Clash of World Politics. Cambridge: Oxford University Press

Bomberg, E 2017, Environmental politics in the Trump era: An early assessment. Environmental Politics, 26, 5, 956-63 
Bondarouk, E, Mastenbroek, E, 2018 Reconsidering EU compliance: Implementation performance in the field of environmental policy. Environmental Policy and Governance, 28, 1, 15-27

Boyne, GA, Meier, KJ, 2013, Environmental turbulence, organizational stability, and public service performance, Administration \& Society, 40, 8, 799-824

Bramley, G, Bailey, N, Hastings, A, Watkins, D, Crowdace, R, 2012, Environmental justice in the city? Challenges for policy and resource allocation in keeping the streets clean. Environment and Planning A, 44, 3, 741-61

Burns, C, Eckersley, P, Tobin, P, 2019a, EU environmental policy in times of crisis, Journal of European Public Policy, doi: 10.1080/13501763.2018.1561741

Burns, C, Tobin, P, Sewerin, S, (eds) 2019b, The Impact of the Economic Crisis on European Environmental Policy. Oxford: Oxford University Press

Cairney, P, 2016, The Politics of Evidence-Based Policy Making. Basingstoke: Palgrave

Cepiku, D, Mussari, R, Giordano, F, 2016, Local governments managing austerity: Approaches, determinants and impact. Public Administration, 94, 1, 223-243

Chorianopolous, I, Tselepi, N, 2019, Austerity urbanism: Rescaling and collaborative governance policies in Athens, European Urban and Regional Studies, 26, 1, 80-96

Davidescu, S, Ralitsa, H, Maltby, T, 2018, Two steps forward, one step back: Renewable energy transitions in Bulgaria and Romania, Public Administration, 96, 3, 611-25

Davies, JS, Blanco, I, 2017, Austerity urbanism: Patterns of neo-liberalisation and resistance in six cities of Spain and the UK, Environment and Planning A, 49, 7, 1517-36 
Davoudi, S and Bell, D, (eds), 2016, Justice and Fairness in the City: A Multi-Disciplinary Approach to 'Ordinary' Cities, Bristol: Policy Press

Di Mascio, F, Natalini, A, 2015, Fiscal retrenchment in Southern Europe: Changing patterns of public management in Greece, Italy, Portugal and Spain. Public Management Review, 17, 1, 129-48

Dunsire, A, Hood, C, Huby, M, 1989, Cutback Management in Public Bureaucracies: Popular Theories and Observed Outcomes in Whitehall, Cambridge: Cambridge University Press

Eckersley, P, 2018, Power and Capacity in Urban Climate Governance: Germany and England Compared. Oxford: Peter Lang

Elston, T, Dixon, R, 2019, The effect of shared service centers on administrative intensity in English local government: a longitudinal evaluation, Journal of Public Administration Research and Theory, doi: 10.1093/jopart/muz002

Ferry, L, Coombs, H, Eckersley, P, 2017, Budgetary stewardship, innovation and working culture: identifying the missing ingredient in English and Welsh local authorities' recipes for austerity management, Financial Accountability and Management 33, 2, $220-243$

Fitzgerald, A, Lupton, R, 2015, The limits to resilience? The impact of local government spending cuts in London, Local Government Studies, 41, 4, 582-600

Freeman, J, Hannan, MT, 1975, Growth and decline processes in organizations, American sociological review, 40, 2, 215-228 
Gershon, P, 2004, Releasing resources to the front line: Independent review of public sector efficiency. London: HMSO

Gleeson, D, Legge, D, O’Neill, D, Pfeffer, M, 2011, Negotiating tensions in developing organizational policy capacity: comparative lessons to be drawn, Journal of Comparative Policy Analysis: Research and Practice, 13, 3, 237-63

Goldsmith, MJ, Page, EC, 2010, Changing Government Relations in Europe: From Localism to Intergovernmentalism, London: Routledge/ECPR

Gravey, V, Jordan, A, 2016, Does the European Union have a reverse gear? Policy dismantling in a hyperconsensual polity, Journal of European Public Policy, 23, 8, 1180-98

Gray, M, Barford, A, 2018, The depths of the cuts: the uneven geography of local government austerity, Cambridge Journal of Regions, Economy and Society, 11, 3, 541-563

Green-Pedersen, C, Christiansen, FJ, Euchner, EM, Jensen, C, Turnpenny, J, 2012, Dismantling by default? The indexation of social benefits in four countries, in Bauer, MW, Jordan, A, Green-Pedersen, C, Héritier, A (eds), Dismantling Public Policy: Preferences, Strategies, and Effects, Oxford Scholarship online, doi: 10.1093/acprof:oso/9780199656646.003.0006

Hastings, A, 2009, Poor neighbourhoods and poor services: Evidence on the "rationing" of environmental service provision to deprived neighbourhoods, Urban Studies, 46, 13, $2907-27$

Hastings, A, Bailey, N, Bramley, G, Gannon, M, Watkins, D, 2013, The cost of the cuts: The impact on local government and poorer communities, York: Joseph Rowntree Foundation 
Hastings, A, Bailey, N, Gannon, M, Besemer, K, Bramley, G, 2015, Coping with the cuts? The management of the worst financial settlement in living memory, Local Government Studies, 41, 4, 601-21

Hood, C, 2010, The Blame Game: Spin, Bureaucracy, and Self-Preservation in Government, Princeton, NJ: Princeton University Press

Howlett, M, 2014, Why are policy innovations rare and so often negative? Blame avoidance and problem denial in climate change policy-making, Global Environmental Change, $29,395-403$

Howlett, M, 2009, Policy analytical capacity and evidence-based policy-making: Lessons from Canada, Canadian Public Administration, 52, 2, 153-75

Howlett, M, Lindquist, E, 2004, Policy analysis and governance: Analytical and policy styles in Canada, Journal of Comparative Policy Analysis: Research and Practice, 6, 3, 22549

Jayasuriya, K, 2004, The new regulatory state and relational capacity, Policy \& Politics, 32, 4, $487-501$

Jordan, AJ, Green-Pedersen, C, Turnpenny, J, 2012, Policy dismantling: An introduction, in Bauer, MW, Jordan, A, Green-Pedersen, C, Héritier, A (eds), Dismantling Public Policy: Preferences, Strategies, and Effects, Oxford Scholarship online, doi: 10.1093/acprof:oso/9780199656646.003.0001

Jordan, AJ, Bauer, MW, Green-Pedersen, C, 2013, Policy dismantling, Journal of European Public Policy, 20, 5, 795-805 
Kim, DR, Yoon, JH, 2018, Decentralization, government capacity and environmental policy performance: A cross-national analysis, International Journal of Public Administration, 41, 13, 1061-71

Kim, Y, Warner, ME, 2016, Pragmatic municipalism: Local government service delivery after the Great Recession, Public Administration, 94, 3, 789-805

Kuhlmann, S, Bouckaert, G, (eds), 2016, Local Public Sector Reforms in Times of Crisis. London: Palgrave Macmillan

Lampropoulou, M, 2018, Policy responses to the Eurozone crisis: A comparative analysis of southern European administrations, Public Policy and Administration, doi: $10.1177 / 0952076718807736$

Levine, C, 1978, Organizational decline and cutback management, Public Administration Review, 38, 4, 316-25

Lodge, M, Wegrich, K, (eds), 2014, The Problem-Solving Capacity of the Modern State: Governance Challenges and Administrative Capacities, Oxford: Oxford University Press

Lowndes, V, McCaughie, K, 2013, Weathering the perfect storm? Austerity and institutional resilience in local government, Policy \& Politics, 41, 4, 533-49

Lowndes, V, Gardner, A, 2016, Local governance under the Conservatives: Super-austerity, devolution and the smarter state, Local Government Studies, 42, 3, 357-375

Matthews, F, 2012, Governance and state capacity, in Levi-Faur, D, (ed), The Oxford Handbook of Governance, Oxford: Oxford University Press 
McKinley, W, 1987, Complexity and administrative intensity: The case of declining organizations, Administrative Science Quarterly, 32, 1, 87-105

Meier, KJ, O'Toole, LJ, 2009, The dog that didn't bark: How public managers handle environmental shocks, Public Administration, 87, 3, 485-502

Morris, Z, 2016, Constructing the need for retrenchment: Disability benefits in the United States and Great Britain, Policy \& Politics, 44, 4, 609-26

National Audit Office, 2018a, Financial sustainability of local authorities 2018. Available at www.nao.org.uk/report/financial-sustainability-of-local-authorities-2018/

National Audit Office, 2018b, Financial sustainability of local authorities 2018 visualisation. Available at https://www.nao.org.uk/highlights/financial-sustainability-of-localauthorities-2018-visualisation/

Newman, J, Cherney, A, Head, BW, 2017, Policy capacity and evidence-based policy in the public service, Public Management Review, 19, 2, 157-74

O’Toole, LT, Meier, KJ, 2009, In defense of bureaucracy, Public Management Review, 12, 3, $341-361$

Painter, M, Pierre, J, (eds), 2005, Challenges to state policy capacity: Global trends and comparative perspectives, London: Palgrave Macmillan

Parrado, S, 2014, Analytical capacity, in Lodge M, Wegrich K (eds), The Problem-Solving Capacity of the Modern State: Governance Challenges and Administrative Capacities, Oxford: Oxford University Press 
Parsons, W, 2004, Not just steering but weaving: Relevant knowledge and the craft of building policy capacity and coherence, Australian Journal of Public Administration, 63, 1, 4357

Peters, BG, 2015, Policy capacity in public administration, Policy and Society, 34, 3-4, 219-28

Pierson, P, 1994, Dismantling the Welfare State: Reagan, Thatcher and the Politics of Retrenchment, Cambridge: Cambridge University Press

Pill, M, Guarneros-Meza, V, 2018, Local government under austerity: hybrid organisations and hybrid officers, Policy \& Politics, 46, 3, 409-25

Pimlott, D, Giles, C, 2010, UK unveils dramatic austerity measures. Financial Times, available from https://www.ft.com/content/53fe06e2-dc98-11df-84f5-00144feabdc0

Pollex, J, Lenschow, A, 2019, Many faces of dismantling: hiding policy change in nonlegislative acts in EU environmental policy, Journal of European Public Policy, DOI: $10.1080 / 13501763.2019 .1574869$

Sausman, C, Oborn, E, Barrett, M, 2016, Policy translation through localisation: Implementing national policy in the UK, Policy \& Politics, 44, 4, 563-89

Schaffrin, A, Sewerin, S, Seubert, S, 2015, Toward a comparative measurement of climate policy output, Policy Studies Journal, 43, 2, 257-82

Schmidt, E, Groeneveld, S, Van de Walle, S, 2017, A change management perspective on public sector cutback management: Towards a framework for analysis, Public Management Review, 19, 10, 1538-55 
Sørensen, EM, Hansen, HF, Kristiansen, MB, (eds), 2017, Public Management in Times of Austerity, London: Routledge

Standring, A, 2018, Depoliticising austerity: narratives of the Portuguese debt crisis 2011-15, Policy \& Politics, 46, 1, 149-164

Steccolini, I, Jones, M, Saliterer, I, 2017, Governmental Financial Resilience: International Perspectives on How Local Governments Face Austerity, Bingley: Emerald

Steinebach, Y, Knill, C, 2017, Still an entrepreneur? The changing role of the European Commission in EU environmental policymaking, Journal of European Public Policy, $24,3,429-46$

Tobin, P, 2017, Leaders and Laggards: Climate Policy Ambition in Developed States, Global Environmental Politics, 17, 4, 28-47

Weale, A, 1999, European environmental policy by stealth: The dysfunctionality of functionalism?, Environment and Planning C: Government and Policy, 17, 1, 37-51

Weaver, RK, Rockman, B, (eds), 1993, Do Institutions Matter? Government Capabilities in the United States and Abroad, Washington, DC: Brookings Institution

Webb, CJR, Bywaters, P, 2018, Austerity, rationing and inequity: Trends in children's and young people's services expenditure in England between 2010 and 2015, Local Government Studies, 44, 3, 391-415

Wu, X, Ramesh, M, Howlett, M, 2015, Policy capacity: A conceptual framework for understanding policy competences and capabilities, Policy and Society, 34, 3-4, 165-71 
Wurzel, RKW, Zito, AR, Jordan, AJ, 2013, Environmental Governance in Europe: A Comparative Analysis of New Environmental Policy Instruments. Cheltenham: Edward Elgar 